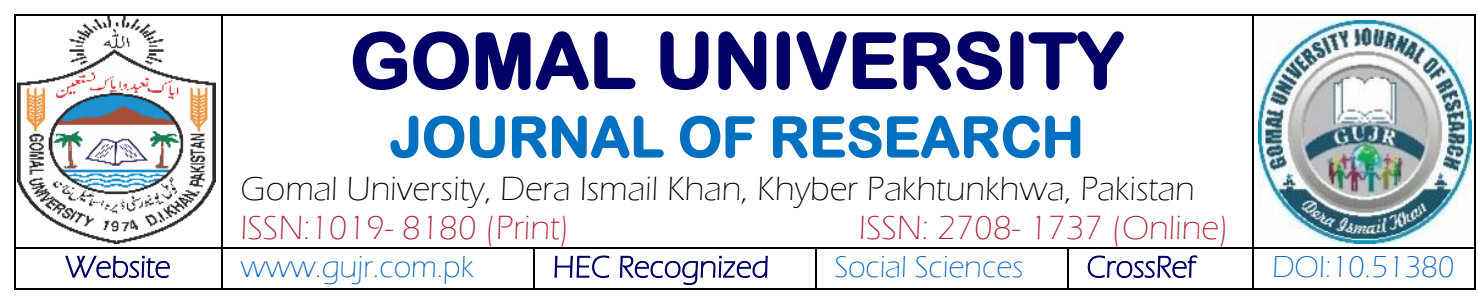

\title{
ASSESSMENT OF INDIVIDUAL AND INSTITUTIONAL INVESTOR'S INVESTMENT BEHAVIOR DURING COVID-19. A CASE OF EMERGING ECONOMY
}

\author{
Sybert Mutereko', Abid Hussain² \& Aamir Sohail ${ }^{3}$ \\ Ischool of Management and governance university of Kwazulu-Natal, SOUTH AFRICA \\ 2Director, The High Aims School Systems, Jahan Khan Bhakkar, (Punjab), Pakistan \\ ${ }^{3}$ Department of Management \& Administrative Sciences, University of Sargodha, Bhakkar
}

\section{\begin{tabular}{l|l} 
KEYWORDS & ABSTRACT
\end{tabular}}

Investment Decisions,

Individual Investors,

Funds Managers \&

COVID-19

In the study of stock investment in capital market by investors in Pandemic

Covid-19, it is always carried out rationally. Indeed, the decisions on stock investments are not always rational. The main purpose of this research is to analyze the behavioral factors that affect the preferences of individual's investors and fund managers in the emerging stock market, Pakistan Stock

\section{Article History}

Date of Submission:

09-07-2021

Date of Acceptance:

20-09-2021

Date of Publication:

30-09-2021

Exchange. The data of this research were collected through interviews semi structured with the five investor and five fund managers from the stock exchange from Pakistan. The researchers used thematic analysis for data interpretation. The major findings stress that retail investors are more effected by behavioral biases in comparison with fund managers. Further, the results shows that there are some major biases which are effecting both type of investors such as: Herding, Market, Prospect, Overconfidencegambling errors and Anchoring-ability bias. This study fills a gap in literature on investor psychological response during pandemic epidemic. According to the report, policymakers should devise a strategy to combat COVID-19. To avoid future catastrophes, government should control the health-care budget.

\begin{tabular}{|c|c|}
\hline & (c) () \&) 2021 Gomal University Journal of Res \\
\hline Corresponding Author & sybert Mutereko: sybert@ukzn.ac.za \\
\hline $\mathrm{DOl}$ & https://doi.org/10.51380/gujr-37-03-02 \\
\hline
\end{tabular}

\section{INTRODUCTION}

In Wuhan, province of Hubei, China, at the end of December 2019, mysterious pneumonia was created. Chinese scientists say that new coronavirus spreads much more rapidly than the 2003 SARS virus in China that killed around 800 people world-wide (Callaway, Ledford \& Mallapaty, 2020). On 11 March 2020, the World Health Organization (WHO) announced a pandemic for the corona virus. Because of COVID-19 pandemic status, governments have chosen to lock down or to complete isolation/ quarantine in various countries. A number of the countries, including 
China, Spain, Italy and Malaysia, have enforced loads by closing all the access to public facilities and transportation to prevent spread of corona virus. Pakistan itself has a large-scale physically distant social restriction policy. The lock-down or large social restrictions have slowed down the economy, which has also affected stock investments on the Pakistan Stock exchange (PSX). There are two approaches to financial decision making in study of capital markets investment. Fama in (1965), efficient market hypothesis theory describes investors being rational, making error free choices, securities always being efficient and priced and equitable expectations of securities.

In conventional theory investor make decisions with variety of the potential actions because it is assumed that investors are consistent in decision making. When the element of risk is involved then it becomes difficult for investors to take decisions under uncertainties. As investors have their own perception in term of investment decisions so, it is critical to follow optimal expected utility theory. Two types of investors investing in PSX are mainly involved. Individual investors are people who buy shares on behalf of themselves. They are trading in lesser quantities. One or co-managers may be fund manager to administer other people stocks. Both investors share actively in the activities of stock markets. Financial information is difficult for small investors to process For the small investor process the financial markets is difficult. The more problems for small investors in comparison to fund managers by taking reasonable or precise decisions (Lu, 2010). Different factors are affecting stock selection decision of investors. In researchers are active to know about diverse investors behavior and market anomalies (Mak, 2017). Investors affected by emotional, psychological and behavioral factors. They make poor investment decisions because of behavioral biases (Ricciardi, 2012). Sohail, Husssain, Abid, and Qurashi (2020). The most psychological and inferential factors have least influence on the investment decision of the retail investor.

Research shows in particular that market volatility, investor faith, herding government policies, broker counseling, political stability, and financial returns are main factors, but social position, religious faiths, and family opinion play the least part in the selection of individual investors' stock. The COVID-19 is still affecting both the global economy and market of financial As a the spread of the cornavarious all over world, most investors face their red colour portfolios, while current pandemic situation still presents opportunities. During economic upturn, traditional investment strategies were well investigated and well documented. the strategies of traditional investments are well documented. However few research papers were designed to in pandemic times investment decisions. The recent studies exploratory as specifically in context of Pakistan (Sohail et al., 2020). The major problem prevails in Pakistan stock exchange is that individual investors and fund managers are facing various challenges regarding portfolio management. They behavioral biases effects decisions of investors and performance of PXS and ultimately the Pakistan economy. Therefore major aim of this study is to investigate the factors effecting investor investment decisions in PSX particularly in case of retail investors and fund managers. In this way this study will improve the performance of investors as well as boost the economy of Pakistan.

\section{LITERATURE REVIEW}

Different factors are affecting stock selection decision of investors. In recent the researchers are working to know about the different investors behavior and market anomalies (Mak, 2017). Investors affected by emotional, psychological and behavioral factors. They make poor investment 
decisions because of behavioral biases (Ricciardi, 2012). The psychosomatic factors are decision making inclinations that are delivered inside by person through the two frameworks of human reasoning. In light of this viewpoint, basic decision making is mental accounting - full of feeling process, assumption or sentiments, and temperament (Jagongo \& Mutswenje, 2014). Others may need to pursue religion necessities by putting resources into Shari'ah-agreeable organizations. Being Shari'ah-agreeable, it becomes imperative to Muslim financial specialists while choosing organizations with the end goal of venture. Adewale and Haron, (2016), interfacing with each other is significant in financial exchange and speculation since it enables stock agents to speak with different stockbrokers and customers. Portfolio directors collaborate with experts, they speak with CEOs and officials and they even structure nearby affiliation (for example League of Investment.

The retail investors additionally look for and share data with their relatives, companions and neighbors about ventures. People can effectively be made a decision by the sort of companions they keep (Messis \& Zapranis, 2014), the presence of herding is an additional risk factor for the investors. So, the volatility measure is emphatically influenced by presence of herding behavior. The financial exchange uncertainty and securities exchange returns are to great extent controlled by the sentiments of the speculators (Howard, 2014). The investor emotionally disturb when he gain the loss from the sample size (Singh, 2012b). The experience of retail and fund manager is also a key factor for investment decision making (Mohamad \& Perry, 2015a) and (Jaiyeoba \& Haron, 2016). The people repeat the past favorable memories and avoid the bad one (Barber \& Odean).To avoid anchoring, investors need to select from different options and consider more than one reference point of information (Ricciardi, 2012). Comparability between traditional and behavioral finance theory and irrational decisions of the investors is the form of biases (Marchand, 2012). Behavioral finance is the theory is to understand the rational decisions of investors and reasons of volatility in market. The investors invest in different portfolio under uncertainty.

The final decision of an investor for investment, it is an important indicator (Hoffmann, 2015). Herding instinct in financial market is consider as tendency of action which investors followed (Dunusinghe \& Ranasinghe, 2015). Investors make decisions under the prospect of different choices, especially in the world of uncertainty (Chang, Young, Hildawa, Santos, \& Pan, 2015). Knowledge of the past experience and past performance in financial market indices influence future investment decision (Cohen \& Kudryavtsev, 2012). However, the investors attempt to outperform in market to recognize higher returns on investment portfolios Investors attempts in the markets to get more return in the markets (Oehler, 2018). The elements of the over confidence is to incline investors knowledge abut the investment (Singh, 2012a) while making investment decision, investors follow herding bias they start imitating the irrational behavior of other. When investors tend to follow the decisions of noise traders (Kumar \& Goyal, 2015). Disposition effect can be reduced by focusing on overall saving goal (Aspara \& Hoffmann, 2015). There is no emotional finance theory that conclude there is need to make check list of common behavioral anomalies that make help to form portfolio and know about psychological traits of the investors.

Investors is not be able to attain maximum return and rational behavior until they understand the sentiments inherent in decision making (Joo \& Durri, 2015). Through behavioral finance theory fund managers and individual investors improve their irrational decisions. This research 
provide help investors to reduce uncertain decisions for investment and raise their confidence (Sajid, 2015). Investors need to use both update and past information and not to cling onto one specific loss experienced (Dickason \& Ferreira, 2018). Even with knowledge and information on how to make investment decision and realizing sound investment remain problematic due to various challenges facing by investors during portfolio selection (Jaiyeoba \& Haron, 2016). For informed investment decisions, as investor it is highly important to understand nation's economy. This is just since when economy fluctuate, such variations could affect all industrial sector. Investors must put into consideration that how to evaluate the fluctuated economy (Mohamad \& Perry, 2015a). Knowing about the investor's personal experience is particularly important factor, whether such past experiences affect their future participation. Investors could remain objective and not follow the greed, fear, emotions, noise traders and information (Haron, 2017).

\section{METHODOLOGY}

The research design of the study is qualitative. Non-probability sampling technique has been used to conduct survey research strategy. Target population for this study is retail investors and fund managers who regularly invest in Pakistan stock market. Sample has been drawn by using convenience sampling. Interviews were collected from Pakistan stock exchange (Lahore region). Five fund managers and five retail investors were interviewed to analyze their investment decision behavior. They have more than one year experience of stock market as investor. Fund managers have more knowledge, involvement or practice of stock market. All the respondents have diverse portfolios. Authors most probably extended an interpretive method for the current research (Bryman \& Bell, 2007). Therefore, qualitative method is used as it's a simple term to explore the study which is based on the behavioral finance (Alexander, 2004; Woods \& Trexler, 2001).

The subjective information is aroused through semi-structured interviews led with five retail financial specialists and five fund managers - total ten interviews - in Lahore, Pakistan. As per recommendations of (Malterud, Siersma \& Guassora, 2015; Guest, 2006; Jaiyeoba, Adewale, Haron, \& Ismail, 2017) that six to twelve interviews are sufficient for required information for nature of this study. Thematic analysis is used as interviews were carried out at the beginning in order to prepare the interviewee for data collection procedure: Data shortening: Technical content analysis was introduced for similarities and differences in topics (Miles, Huberman, \& Saldana, 2014). In this connection, this is the organized theme and the classification of the pattern topics, ideas and the concepts. For this purpose, the second phase the themes were declare one by one and the maintained the exact citation (Jaiyeoba \& Haron, 2016), The second phase the themes were declare one by one and the maintained the exact citations (Zakaria, 2015).

\section{RESULTS OF STUDY}

The main results have been presented in this section that thus further helped in reaching the conclusion.

\section{Interviewee Characteristics}

This interview was held on Pakistan Stock Exchange with five individual and five institutional investors and identified several factors which could influence investment decision making. No investor of this kind has less than one year experience in investments. All respondents are male and Pakistani and invest in PSX at moment in different situations. Everyone has degrees which 
are applicable to corporate management. Consequently, everyone has excellent stock market understanding.

Table 1

Interviewees Background Information

\begin{tabular}{ccclcc}
\hline Interviewees & Gender & Age & Highest Education & Year of Involvement & Investment in Assets \\
\hline 1 & Male & 42 & M.com & 10 & Yes \\
2 & Male & 34 & M.Phil. & 7 & Yes \\
3 & Male & 47 & MBA & 12 & Yes \\
4 & Male & 32 & ACMA Qualified & 7 & Yes \\
5 & Male & 38 & ACMA Qualified & 10 to 12 & Yes \\
& & & $\quad$ Retail Investors & & Yes \\
6 & Male & 50 & Masters & 3 & Yes \\
7 & Male & 52 & Bachelor & 2 & Yes \\
8 & Male & 32 & MBA & 5 & Yes \\
\hline 9 & Male & 32 & Marketing & 6 & Yes \\
\hline
\end{tabular}

\section{Interviews}

The interviews with the funds managers and retail investors revealed the different behavioral propensities with regards to investment decision. Consequently, in this session five themes are emerged.

\section{Investors' Experiences During COVID-19 Pandemic}

The experience of stock market investors and how their experiences effect prospect of Pakistan market. The stock market investors are well awarded about stock. The experience of investors about investment is important and long term effect of stock market. Followings experiences are witten in details that are about retail investors and fund managers (Strahilevitz, Odean \& Barber, 2011).

My experience in stock market is about ups and downs. As you know, "investment in equity Involves risk, whenever we talk about risk, there will be good and bad times. Investment in trading involves less risk and get return within less time" (Funder Manger). "Usually investors remain active in stock market whatever the condition of market and economy" (Funder Manger)

"I have some experience of the equity market and I think investment in equity, is a long-term process, one can take return after certain period. I usually prefer to invest in trading whether in the daily, weekly or monthly shares for sake to take return as quickly as possible" (Retail Investor).

\section{Investors Understanding Pakistani Economy}

In this section, all respondents expressed use of some forms of economic understanding, and ultimately the experience of trying to understand the economy for investment decision making 
process. For making investment decisions, part of ultimate analysis stage implicit to understand economy (Mohamad \& Perry, 2015b). As global inflation, central bank, fiscal policies, dollar prices and interest rates affects the certain or all industries in country. Thus, economic condition have definitive impact on stock prices so, investors must take into account the economic activities. Thus, the following experiences are illustrated by the respondent as the retail investors and fund managers:

Being a fund manager, we must analyze the historical and future information. For historical data we have to follow central bank policies and information like employments, industrial production index, gross domestic production, interest rates and inflation rates. For future data, we have to investigate the yearly budget, fiscal policy and any updating information related to changes in the policies which affect the investors' decision-making power" (Fund Manager Interviewee 1).

You need to know trends of economy whether "economy is stable or not especially in current scenario where CoVID-19 impact adversely. IMF decisions directly influence financial market when it raises interest rates and devalued "rupee" which can shake the stock market" (Fund manager Interviewee 5). "Knowledge about economy is very essential. As financial reserve decline it has bad impact on stock market and during COVID-19 it's very essential to know about the exact status of the current economy to make the rational decisions" (retail investor Interviewee 2).

Sometime news may not be accurate "source of information, we must follow the other sources of information sharing related to economic issues" (retail investor Interviewee 3). In this regard, it is defined that during COVID-19, to know about economic and market condition is essential and for this, newspaper and social media play vital role. In this connection, they follow such information which are available and open on social place. So, they are hited by availability bias.

\section{Priorities for Company Selection}

This section of decision making is very important for investors. While selecting company for investment purpose, it is one of the key drivers for investors. For sound investment decision, it is necessary for investors to understand companies' financial positions and other key factors. While making investment decisions, several factors such as Shariah-compliant, economic and market conditions, technical analysis, fundamental analysis, judgmental, investment returns, etc. all are must taking into account(A. Jagongo, \& Mutswenje, V. S. \& Jaiyeoba, 2014;2016). The following experiences are illustrated by respondent as retail investors and fund managers:

As a portfolio manager, you need to "read thoroughly the annual reports and extract relevant information. You need to understand firm settings. We must also need to forecast company's performance and earnings. We make use of forecast earnings; it is from this that we know whether company is attractive or not. We must follow the analysts' reports about company management. Moreover, it is difficult to how to ascertain undervalued companies separate from big companies which must be proportion of our portfolio"(Fund manager Interviewee No. 3).

Retired person select company on the "basis of company dividend. But investors consider the return on assets"(Fund Manager Interviewee No. 5). In this connection, "I put my investment in blue chip Company without side line share, because Blue Chip Company has high earning 
per share" (Retail Investor Interviewee 2). Consequently, "I consider the companies that are Shariah-compliant, and thus also consider their market price" (Retail Investor Interviewee No. 4).

\section{Type \& Source of Investment Advice}

This section is based on way investors take additional information from third Party/ consultant/ friends/relatives. Mostly investors do not rely on consultants and they check company general trends from fundamental and technical analysis online, journals, newspapers and magazines. They do not rely totally on third party for additional information as it just provides wind data which is prevailing in market which cannot be checked analytically. Similar to above segment of influences of emotional and psychological biases, this section also found that retail investors herd information more as compared to the fund managers. Here are some quotations from the interviewees:

We seek information from the "major shareholders involved in certain firms, thus, the firm's management, CEOs of the firms and activities of the firms. Most considerable is that, some firms might look good, but their valuation is too weak, we have to stress on firms'valuation points: its discounted cash flows, earnings per share for seeking information associated with investment decision making process. We must also take into consideration the firm's last five years performance, and their future evaluation on such basis" (Fund manager Interviewee No.4).

It is "difficult to trust on third party or friends. I receive the information from online SWOT analysis of the required companies" (Fund manager Interviewee No.2). In this regard, "I seek investment information from media, PSX site, and online forum (Facebook pages) where information is shared by different investors. In this connection, thus, I used to discuss with my friend who is also an investor. I get good piece of advice from him" (Retail Investor Interviewee No.2).

\section{Challenges Faced in Making Investment Decision}

This part describes the challenges faced by investors while making investment decisions. It is found that, investors are facing various challenges while making investment decisions. Buying at low price and selling at high price is not accurate process for investment decisions, investors face different challenges (Riaz \& Rawalpondi, 2012). It is hard to realize investment objectives due to several challenges that are confronted by investors in making investment decisions (Jaiyeoba \& Haron, 2016). To support this section following are responses of the fund managers and retail investors.

When the recession will be "prevailing in market, everyone will be panic. You know proper timing of buying and selling exist a lot. In this drive, it becomes the huge challenge" (Fund manager Interviewee No. 1). The "Market affect your portfolio differently, but the reaction of different stock towards market sensitivity is a vast challenge" (Fund manager Interviewee No. 3).

As an investor, one of the "most challengeable issue is source of income and tax on it. Tax is a burden" (Retail investors No. 2). "In long term financing, one can put money under Shariah compliant but in day trading it is all in all gambling" (Retail investors No. 3). "Volatility in market place and Initial Public Offering shares are challengeable aspects" (Retail investors No. 4). 
All the respondents are agree on this point that COVID-19 is the big challenge for both retail investors and fund managers from different perspectives and as due to this market is effecting adversely.

\section{DISCUSSION AND CONCLUSION}

The finding of this study indicates that the investor experiences effect due to investor behavior, the past study indicates the past experiences of the investor bout the investment effects the decision of the investment (Strahilevitz et al., 2011). The past studies indicates investors have less understanding about investment as compare to fund managers. In this connection, they derive information from news, historical information and conveyed by regulatory authorities. Investors give more importance to data that is available smoothly as a contrast to investigate different options and methods. The invest in what you know, avoid those which are unknown or untrusted (Schwartz, 2010). It is concluded that disposition effect persuades underreact to new information prevailing in market. For price determination pattern it includes: new information and investor's preference price related to the current price (Frazzini, 2006). In this connection, financial investors consider the mental inclinations less on the grounds that they have absence of knowledge about such disposition. Consequently, they keep the general view settling on the speculation choices as they have not very much dependent variable data and can't lead special investigation.

So, they can not reduce such predisposition and thus, heuristic improvement is against insightful framework which is performed to ascertain likelihood in a sensible way (Frederick, 2002). In this bias decisions is instantly considered without follow the complicated procedure (Raines \& Leather, 2011). These challenges are assessed by the responses of the interviewees: timing is the main issue, when to buy or sell a stock is so much important at different trade cycle. Market fluctuations affect portfolio and reaction of such portfolios towards stock market sensitivity is a huge challenge. Investors react optimistically when market goes up and pessimistically when the market downturn. Mostly people undervalue what they are and overvalue what they are not (Forbes, 2009). The results of investor's responses revealed that: using authentic and powerful software, company's visit, expert's point of views, strong advice from investment team, learning from past experiences, mistakes in past, enhancement in valuation skills, reading related news, engage with updating the information, holding the different investment classes portfolio and understand that investment returns may be low or high depending on the economic and firms situations.

\section{Limitations and Future Direction}

- This study is conducted only in Pakistan context in stock exchange due to the time as well as other constraint.

- Data for this study was collected for one time only for better understanding data may be collected for more than one time in future.

- Triangulation method may be directed in the future for further clarification in existing study to compare the outcomes .

- This study provides insight platform for scholars, academic writers and professionals to examine behavioral biases of investors and thus to improve their decision making capabilities.This study is helpful for financial professionals to create decisions profiles related to the exchange of securities. 


\section{REFERENCES}

Alexander, A. (2004). "A qualitative exploration of students' experiences with tutorial learning”. ProQuest Dissertationsand Theses, Louisiana State University.

Aspara, J., \& Hoffmann, A. O. I. (2015). Cutyour Losses and Let Your Profits Run: How Shifting Feelings of pPersonal Responsibility Reverses the Disposition Effect. Journal of Behavioral and Experimental Finance, 8, 18-24.

Barber, B. M., \& Odean, T. The Behavior of Individual Investors. Handbook of the Economics of Finance 2, 2013.

Bryman, A., \& Bell, E. (2007). Business Research Methods, Second edition. Oxford University Press, Second edition.

Callaway, E., Ledford, H., \& Mallapaty, S. (2020). Six months of coronavirus: The mysteries scientists are still racing to solve. Nature, 583(7815), 178-179.

Chang, K. H., Young, M. N., Hildawa, M. I., Santos, I. J. R., \& Pan, C. H. (2015). Portfolio Selection Problem Considering Behavioral Stocks. In Proceedings of the World Congress on Engineering, 2.

Cohen, G., \& Kudryavtsev, A. (2012). Investor Rationality and Financial Decisions. Journal of Behavioral Finance, 13, 38-50.

Dickason, Z., \& Ferreira, S. (2018). Establishing a link between risk tolerance, investor personality and behavioural finance in South Africa. Financial Economics.

Dunusinghe, P., \& Ranasinghe. (2015). A. Behavioural Factors Influence on Investment Performance. A Survey of Individual Investors at Colombo Stock Exchange.

Forbes, M. S. (2009). The Behavioral Finance in contemporary era, Wiley. London. Frederick, K. a. (2002).

Frazzini. (2006). The disposition effect and underreaction to news. Journal of Finance, 61, 2017-2046.

Guest, G. (2006). "How many interviews are enough?: An experiment with data saturation and variability". Field Methods, 18 No. 1, 59-82.

Haron, R. (2017). Investment decision behaviour of the Malaysian retail investors and fund managers: Qualitative Research in Financial Markets.

Hoffmann, A. E. A. (2015). How Investor Perceptions Drive Actual Trading and Risk-Taking Behavior. Journal of Behavioral Finance, 16(1), 94-103.

Howard, C. T. (2014). Behavioral Portfolio Management. Journal of Behavioral Finance and Economics, 1-37.

Jagongo, A., \& Mutswenje, V. S., \& Jaiyeoba, H. B., \& Haron, R. (2014;2016). A Survey of the Factors Influencing Investment Decisions : The Case of Individual Investors at the NSE; A qualitative inquiry into the investment decision behaviour of the Malaysian stock market investors. International Journal of Humanities and Social Science, 4(4);8(3), 92-102; 246-267.

Jagongo, A., \& Mutswenje, V. S. (2014). A survey of the Factors Influencing Investment Decisions: The case of Individual Investors at NSE. International Journal of Humanities and Social Science, 4(4), 92-102.

Jaiyeoba, H., \& Haron, J. (2016). A qualitative inquiry into the investment decision behaviour of the Malaysian stock market investors. Qualitative Research in Financial Markets, 8(3), 246-267. 
Jaiyeoba, H. B., Adewale, A. A., Haron, R., \& ISMAIL, C. M. H. C. (2017). "Investment decision behaviour of the Malaysian retail investors and fund managers: A qualitative inquiry". Qualitative Research in Financial Markets.

Jaiyeoba, H. B., \& Haron, R. (2016). A qualitative inquiry into the investment decision behaviour of the Malaysian stock market investors. Qualitative Research in Financial Markets, 8(3), 246-267.

Joo, A. B., \& Durri, K. (2015). Comprehensive Review of Literature on Behavioural Finance. Indian Journal of Commerce and Management Studies, 6(2), 11-20.

Kumar, S., \& Goyal, N. (2015). Behavioural Biases in Investment Decision Making: Asystematic Literature Review. Qualitative Research in Financial Markets, 7(1), 88-108.

Lincoln, \& Guba, L. (1985). The Naturalistic Inquiry,1sted. Sage Publications, Newbury Park, CA.

Lu, L. (2010). 'Asset Pricing and Welfare Analysis with Bounded Rational Investors'. The Financial Review, 45, no. 2, 485-499.

Mak, M. K. (2017). An exploratory study of investment behaviour of investors. International Journal of Engineering Business Management, 9, 1-12.

Malterud, K., Siersma, V. D., \& Guassora, A. D. (2015). "Sample size in qualitative interview studies: guided by information power", QualitativeHealth Research, 1-844.

Marchand, M. (2012). Behavioral Biases in Financial Decision Making. Bachelor Theses Finance, 8200, 1-28.

Messis, P., \& Zapranis, A. (2014). Herding Behaviour and Volatility in the Athens Stock Exchange. The Journal of Risk Finance, 15(5), 572-590.

Miles, M., Huberman, M., \& Saldana, J. (2014). Qualitative Data Analysis: An Expanded Sourcebook, 3rd ed. Sage Publications, Thousand Oaks, CA.

Mohamad, S. G. B., \& Perry, C. (2015a). How fund managers in Malaysia make decisions. Qualitative Research in Financial Markets, 7 (1), 72-87.

Mohamad, S. G. B., \& Perry, C. (2015b). "How fund managers in Malaysia make decisions". Qualitative Research in Financial Markets, 7 No. 1, 72-87.

Oehler, A., al, et. (2018). nvestors' Personality Influences Investment Decisions: Experimental Evidence on Extraversion and Neuroticism. Journal of Behavioural Finance, 19(1), 3048.

Orobia, L. A., Byabashaija, W., Munene, J.C., Sejjaaka, S.K., \& Musinguzi, D. (2013). "How do small business owners manage working capital in an emerging economy? A qualitative inquiry". Qualitative Research in Accounting \& Management, 10 No. 2, 127-143.

Raines, G., \& Leather, R. (2011). Behavioural Finance and Post Keynesian-Institutional Theories of Financial Markets. Journal of Post Keynesian Economics.

Riaz, R., L., Hunjra, A. I., \& Rawalpondi, P. (2012). Impact of psychological factors on investment decision making mediating by risk perception. Middle-East Journal of Scientific Research, 12(6), , 12(16), 789-795.

Ricciardi, V. (2012). What is Behavioral Finance? Business, Education and Technology Journal, 2(2), 1-9.

Sajid, M. (2015). Factors Affecting Investment Decision Making: Evidence from Equity Fund Managers and Individual Investors in Pakistan. Journal of Basic and Applied Scientific Research, 5(8), 62-69. 
Schwartz, G. (2010). The Heuristric or rule of thumb. Behavioral finance: The Corporations and markets.

Singh, S. (2012a). Investor Irrationality and Self-Defeating Behaviour: Insights from Behavioural Finance. The Journal of Global Business Management, 8(1), 116-122.

Singh, S. (2012b). Investor irrationality and self-defeating behaviour: Insights from behavioural finance. The Journal of Global Business Management, 8(1), 116-122.

Sohail, Husssain, A., \& Qurashi. (2020). An Exploratory Study to Check Impact of COVID-19 on Investment Decision of Individual Investors in Emerging Stock Market Electronic Research. Journal of Social Sciences and Humanities, 2(4), 1-13.

Strahilevitz, M. A., Odean, T., \& Barber, B. M. (2011). "Once burned, twice shy: how Naive learning, counterfactuals, and regret affect the repurchase of stocks previously sold”. Journal of Marketing Research, 48, pp., S102-S120.

Woods, M., \& Trexler, C. J. (2001). "Linking interpretative theory to practice: examining an underused research tool in agricultural education". Journal of Agricultural Education, $42(2), 68-77$.

Zakaria, Z. (2015). "Acultural approach of embedding KPIs into organisational practices". International Journal of the Productivity and Performance Management, 64 No. 7, 932-946. 